Note

\title{
Sighting rates and prey of Minke Whales (Balaenoptera acutorostrata) and other cetaceans off Cormorant Island, British Columbia
}

\author{
Jared R. Towers ${ }^{1,2, *}$, Christie J. MCMillan ${ }^{1}$, and Rebecca S. PierceY ${ }^{3}$ \\ ${ }^{1}$ Marine Education and Research Society, P.O. Box 1347, Port McNeill, British Columbia V0N 2R0 Canada \\ ${ }^{2}$ Bay Cetology, P.O. Box 554, Alert Bay, British Columbia V0N 1A0 Canada \\ ${ }^{3}$ Hakai Institute, P.O. Box 309, Heriot Bay, British Columbia V0P 1H0 Canada \\ *Corresponding author: jrtowers@gmail.com
}

Towers, J.R., C.J. McMillan, and R.S. Piercey. 2019. Sighting rates and prey of Minke Whales (Balaenoptera acutorostrata) and other cetaceans off Cormorant Island, British Columbia. Canadian Field-Naturalist 133(2): 144-150. https://doi. org/10.22621/cfn.v133i2.2103

\begin{abstract}
From June to August 2012, we conducted over $500 \mathrm{~h}$ of visual surveys from Cormorant Island, British Columbia, to determine behaviour and habitat use patterns of nearby cetaceans. Seven species were documented, but Minke Whales (Balaenoptera acutorostrata) were by far the most common and were observed lunge feeding at the surface on 15 occasions. In addition, this species was documented surface lunge feeding on Pacific Herring (Clupea pallasi) and Pacific Sand Lance (Ammodytes personatus) on 32 occasions during vessel-based cetacean surveys around Cormorant Island between 2010 and 2014. Although Minke Whales are relatively uncommon in British Columbia, these results indicate that they can regularly be found in specific feeding areas during the summer.

Key words: Minke Whale; Balaenoptera acutorostrata; habitat use; feeding ground; Pacific Herring; Clupea pallasi; Pacific Sand Lance; Ammodytes personatus; Cormorant Island; British Columbia

The coastal waters of the eastern North Pacific are home to several species of cetaceans. Many have been exploited by humans and conservation concerns have made them the focus of extensive field studies in recent decades (Ford 2014). Important foraging habitats considered critical for recovery have been identified for depleted populations of Killer Whale (Orcinus orca), Humpback Whale (Megaptera novaeangliae), and Fin Whale (Balaenoptera physalus), and some populations of these species have become increasingly abundant and widespread in coastal waters in recent years (Ford et al. 2009, 2013, 2017; Nichol et al. 2018; Towers et al. 2015, 2018, 2019). Although the distribution and behaviour of less common cetacean species have been recorded (Ford 2014), the foraging ecology and habitat use patterns of some, such as Minke Whale (Balaenoptera acutorostrata), remain poorly understood.

Minke Whale is a small, migratory baleen whale that normally occurs in coastal waters of the eastern North Pacific between spring and fall (Towers et al. 2013). Despite a lack of human exploitation history in

these waters, Minke Whales are relatively rare along the west coast of North America. Ship-based cetacean surveys between California and Washington have documented Minke Whales 18 times between 1991 and 2008 (Barlow and Forney 2007; Barlow 2010). Further north, in the coastal waters of British Columbia, surveys conducted by Williams and Thomas (2007) and Ford et al. (2010) detected only a combined total of 35 Minke Whales during $34290 \mathrm{~km}$ of survey effort.

Directed photo-identification research on Minke Whales in British Columbia and Washington has also documented relatively few unique individuals with totals of only 38 identified between 1977 and 1987 (Dorsey et al. 1990) and 44 between 2005 and 2012 (Towers et al. 2013). Photo-identification data have not been compared between these periods, but at least one individual identified in the 1980s was also documented in the 2010s (J.R.T. unpubl. data). Several other individuals documented on more than one occasion show high degrees of inter- and intra-annual fidelity to certain coastal areas over long periods (Dorsey et al. 1990; Towers et al. 2013).
\end{abstract}


The feeding behaviour of Minke Whales can be difficult to determine because most of it occurs below the water surface. However, in Washington, Minke Whales have been reported surface feeding on Pacific Herring (Clupea pallasi) and Pacific Sand Lance (Ammodytes personatus) on 10 and two occasions, respectively (Hoelzel et al. 1989). Few data on Minke Whale prey have been reported in western Canada, but Minke Whales have also been observed lunge feeding at the surface around Cormorant Island off northeastern Vancouver Island (Towers et al. 2013).

The waters around Cormorant Island are relatively shallow compared to depths of other nearby waterways and the substrate is made up of glaciofluvial gravels and sand. Large tidal fluctuations $(5 \mathrm{~m})$ and varied bathymetry in this area result in strong currents $(<10$ $\mathrm{km} / \mathrm{h}=<5 \mathrm{kts}$ with anything over $2 \mathrm{kts}$ generally considered to have an impact on the movements and behaviour of most commercial and recreational vessel traffic as well as most fish and marine mammals) and upwellings. These environmental variables combine to create favourable habitat for an array of marine species, including several cetaceans in addition to Minke Whales.
To study the behaviour and occurrence of these species non-invasively, we conducted systematic shore-based cetacean observations from Cormorant Island in the summer of 2012 while making concurrent underwater acoustic recordings. This note presents the visual results of this study combined with data from surface predation events by Minke Whales that were opportunistically documented from small research vessels around Cormorant Island from 2010 to 2014. The acoustic results of this study are reported in Nikolich and Towers (2018).

Visual observations of cetaceans were made from the north shore of Cormorant Island at $50^{\circ} 36.140^{\prime} \mathrm{N}$, $126^{\circ} 56.820^{\prime} \mathrm{W}$ (Figure 1). Observers used naked eyes and $15 \times 80$ binoculars (Steiner, Greely, Colorado, USA) with built in magnetic (M) compass and reticle bar mounted on a leveled tripod (Velbon, Tokyo, Japan) to detect cetaceans over an arc of $160^{\circ}$ $\left(272^{\circ} \mathrm{M}-072^{\circ} \mathrm{M}\right)$. Visual surveys were conducted by two or more alternating observers for up to $13 \mathrm{~h}$ /day when Beaufort sea state levels were $\leq 2$ (see http:// www.wdes.org/submissions_bin/WDCS_Shore watch_Seastate.pdf for explanation of Beaufort sea

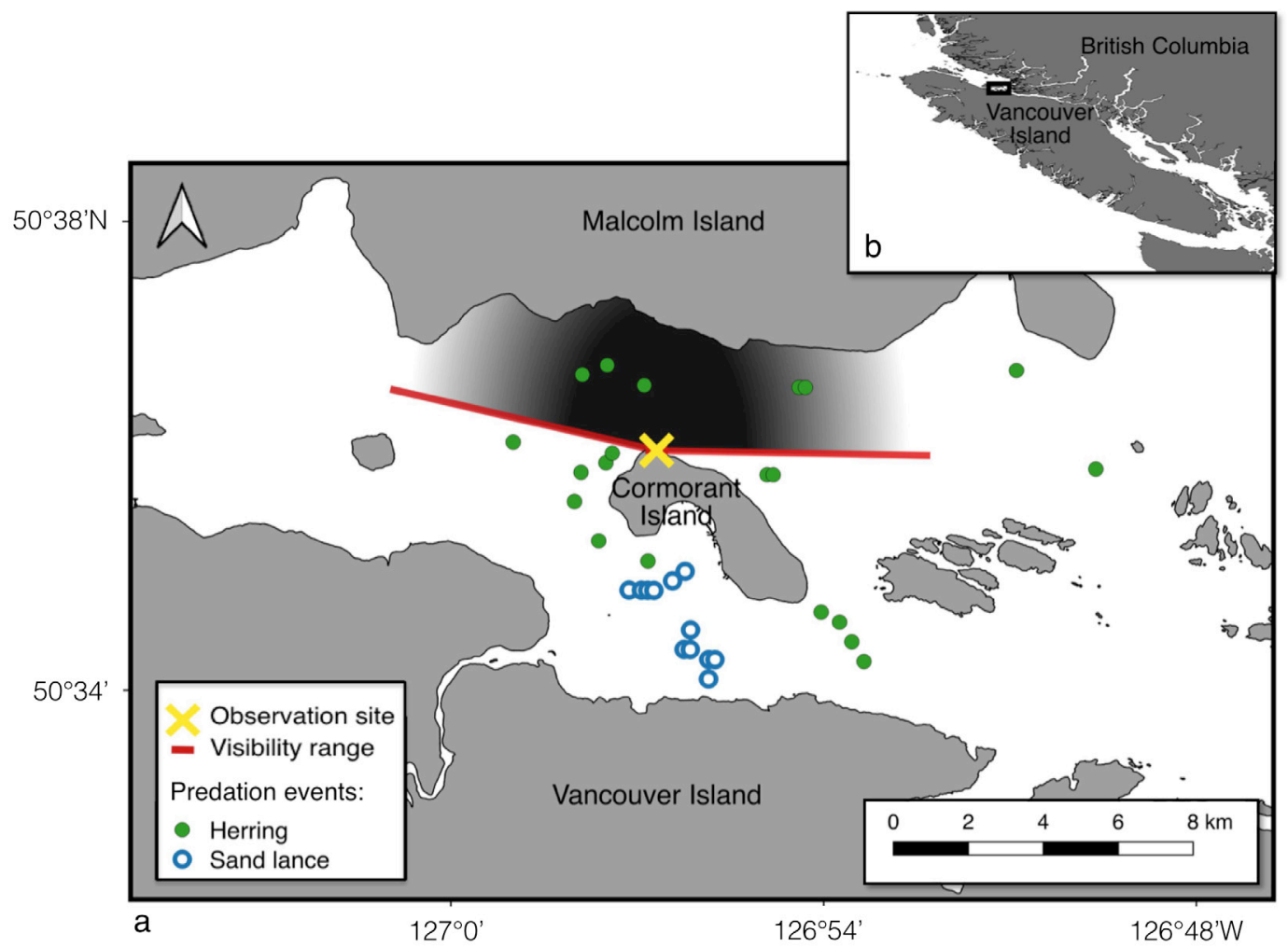

FIGURE 1. The study area off northeastern Vancouver Island, with a. showing the point on Cormorant Island from which observations were made, the arc of visibility, and the locations of Minke Whale (Balaenoptera acutorostrata) predation events and prey species documented from research vessels from 2010 to 2014 in relation to b. the south and central coasts of British Columbia. 
states). Data, including Beaufort sea state, tide height, and notes on visibility, were recorded every $30 \mathrm{~min}-$ utes of survey effort. The time, compass bearing, and reticle distance were recorded each time a cetacean surfaced (Nikolich and Towers 2018), but when Minke Whales and other species were present in the study area, priority was given to recording the surfacings of Minke Whales. The behaviour of cetaceans was noted when apparent, and an effort was made to identify individual whales visually when they were within range. Individual Minke Whale identifications were based on unique natural markings as described and shown in Towers (2011). To reduce any biases arising from animals being missed when sighting effort was focussed in another section of the study area, cetacean occurrence is portrayed in this paper as presence per unit effort (PPUE). A unit of effort was classified as 55-60 minutes of uninterrupted visual surveys and PPUE was defined as the number of effort units that the species was present divided by the total number of effort units.

Between 11 June and 15 August 2012, weather conditions allowed for observers to make shore-based visual surveys on 54 days: 20 in June, 19 in July, and 15 in August (Figure 2). In total, 513 units of visual survey effort were conducted. Seven species of cetaceans were documented: Minke Whale, Humpback Whale, Fin Whale, Bigg's Killer Whale (Orcinus orca; also known as West Coast Transient population), Dall's Porpoise (Phocoenoides dalli), Harbour Porpoise (Phocoena phocoena), and Pacific Whitesided Dolphin (Lagenorhynchus obliquidens; Figure 2). Minke Whales had the highest PPUE (0.44), as they were observed during 224 units of effort (Figure 2; Table 1). Six previously known and individually recognizable Minke Whales were visually identified (M001, M002, M003, M004, M006, and M022; Towers 2011). Harbour Porpoises were the second most commonly present species in the study area followed by Humpback Whales and Dall's Porpoises (Figure 2; Table 1). The species with the lowest PPUE was Fin Whale (Figure 2; Table 1). All species were documented transiting; although most species likely foraged at depth in the study area, only Minke Whales,
Humpback Whales, and Bigg's Killer Whales were observed feeding at the surface. Bigg's Killer Whales were documented preying on a Dall's Porpoise on one occasion, and Minke and Humpback Whales were observed feeding on small schooling fish on 15 and two occasions, respectively. No relation between tidal activity and the foraging behaviour or occurrence of any species was detected.

Between 10 September 2010 and 7 August 2014, predation at the surface by Minke Whales around Cormorant Island was also opportunistically documented from small research vessels on 32 occasions (Figure 3; Table 2). Prey species were visually identified from photographs, video, or samples of remains collected near the surface with a dip-net after the feeding event. Of the predation events, 20 were on Pacific Herring and 12 were on Pacific Sand Lance (Figures 1 and 3; Table 2). Of the six photo-identified Minke Whales involved in these events (Table 2), five were visually documented during the shore-based component of this study.

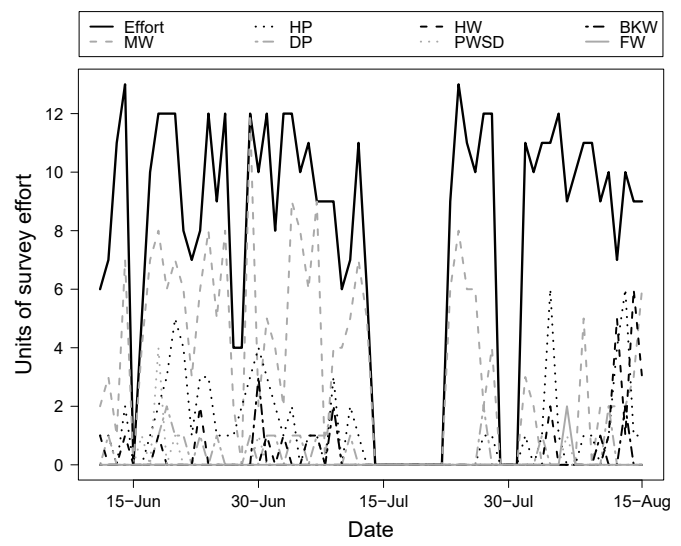

Figure 2. Units of survey effort and the presence per unit effort (PPUE) of each species of cetacean sighted between 11 June and 15 August 2012 off Cormorant Island, British Columbia. $\mathrm{MW}=$ Minke Whale (Balaenoptera acutorostrata), HP = Harbour Porpoise (Phocoena phocoena), $\mathrm{HW}=$ Humpback Whale (Megaptera novaeangliae), DP $=$ Dall's Porpoise (Phocoenoides dalli), PWSD = Pacific White-sided Dolphin (Lagenorhynchus obliquidens), BKW = Bigg's Killer Whale (Orcinus orca), and FW = Fin Whale (Balaenoptera physalus).

TABLE 1. Occurence of cetaceans and presence per unit effort (PPUE) based on sightings from the north shore of Cormorant Island, British Columbia, 11 June to 15 August 2012.

\begin{tabular}{lccccccc}
\hline \hline & MW & HP & HW & DP & PWSD & BKW & FW \\
\hline Days observed & 45 & 39 & 14 & 20 & 5 & 4 & 1 \\
Sightings & 1551 & 109 & 113 & 35 & 23 & 40 & 3 \\
Units present & 224 & 80 & 27 & 23 & 8 & 8 & 2 \\
PPUE & 0.44 & 0.16 & 0.05 & 0.04 & 0.02 & 0.02 & 0 \\
\hline \hline
\end{tabular}

Note: BKW = Bigg's Killer Whale (Orcinus orca), DP = Dall's Porpoise (Phocoenoides dalli), FW= Fin Whale (Balaenoptera physalus), HP = Harbour Porpoise (Phocoena phocoena), HW = Humpback Whale (Megaptera novaeangliae), $\mathrm{MW}=$ Minke Whale (Balaenoptera acutorostrata), and PWSD = Pacific White-sided Dolphin (Lagenorhynchus obliquidens). 

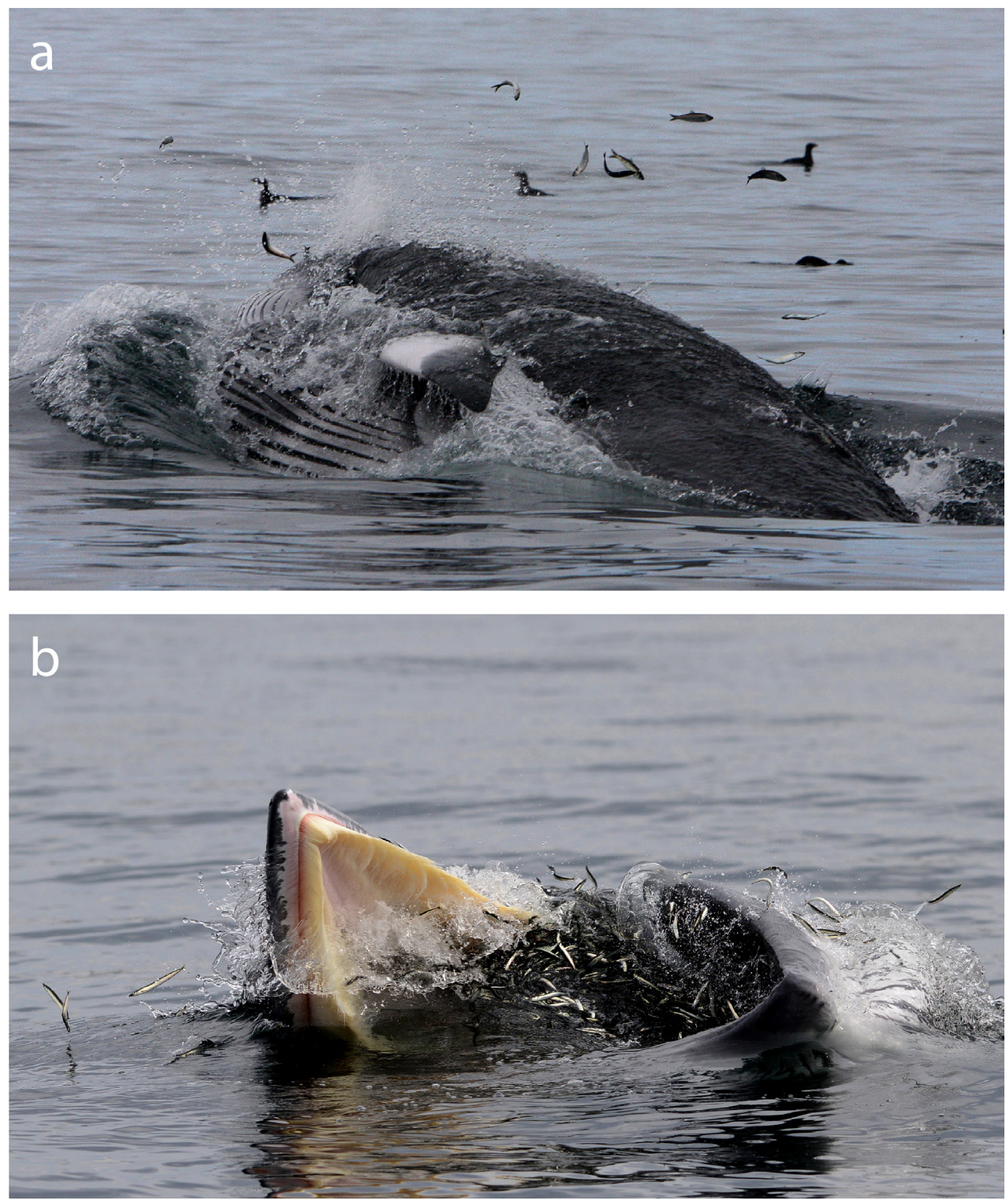

Figure 3. Minke Whale (Balaenoptera acutorostrata) M001 lunging on a. juvenile Pacific Herring (Clupea pallasi) on 18 July 2011 and b. juvenile Pacific Sand Lance (Ammodytes personatus) on 11 June 2014. Photos: Jared Towers.

Of the other species documented in this study, all but Bigg's Killer Whales are also known to feed on Pacific Herring (Walker et al. 1998; Morton 2000; Nichol et al. 2013; McMillan et al. 2018; Towers et al. 2018). Among them, at least the second, third, and fourth most commonly observed species in this study, Harbour Porpoise, Humpback Whale, and Dall's Por- poise also feed on Pacific Sand Lance (Walker et al. 1998; Nichol et al. 2013; Marine Education and Research Society unpubl. data). All species documented are relatively common in many coastal regions of the eastern North Pacific with the exception of Fin Whale. This species is rarely observed in the inshore waters around Vancouver Island and the individual 
TABLE 2. Dates of foraging events by identified Minke Whales (Balaenoptera acutorostrata) around Cormorant Island, British Columbia, from 2010 to 2014, and prey species consumed: Pacific Herring (Clupea pallasi) and Pacific Sand Lance (Ammodytes personatus).

\begin{tabular}{lcl}
\hline \hline Date & Individual whale & \multicolumn{1}{c}{ Prey species } \\
\hline 10 Sep. 2010 & M004 & Pacific Herring \\
10 Sep. 2010 & M006 & Pacific Herring \\
18 Jul. 2011 & M001 & Pacific Herring \\
27 Jul. 2011 & M006 & Pacific Herring \\
1 Aug. 2011 & M022 & Pacific Herring \\
18 Sep. 2011 & M007 & Pacific Herring \\
18 Sep. 2011 & M007 & Pacific Herring \\
15 Jul. 2012 & M001 & Pacific Sand Lance \\
15 Jul. 2012 & M004 & Pacific Sand Lance \\
15 Jul. 2012 & M001 & Pacific Sand Lance \\
15 Jul. 2012 & M002 & Pacific Sand Lance \\
16 Jul. 2012 & M001 & Pacific Sand Lance \\
16 Jul. 2012 & M004 & Pacific Sand Lance \\
18 Jul. 2012 & M004 & Pacific Sand Lance \\
18 Jul. 2012 & M004 & Pacific Sand Lance \\
18 Jul. 2012 & M004 & Pacific Sand Lance \\
\hline \hline
\end{tabular}

observed is likely the same one photographed nearby the previous day as reported in Towers et al. (2018).

Although the species observed in this study are widely distributed throughout the eastern North $\mathrm{Pa}$ cific (Ford 2014), the high rates of Minke Whale sightings compared with other cetacean species and numerous predation events recorded confirm this area as an important summer feeding ground for some individual Minke Whales that show intra- and inter-annual fidelity to these waters. To our knowledge, no other shorebased cetacean study in the eastern North Pacific has documented such high rates of Minke Whale occurrence, and the feeding observations reported here are among the first of this species in western Canada.

The environmental variables in the waters around Cormorant Island that create favourable habitat for Minke Whales and their prey are not unlike those documented in Minke Whale habitat in other regions. Minke Whale occurrence is positively correlated with shallow water that is near deeper water in Washington (Hoelzel et al. 1989) and Scotland (Robinson et al. 2009). The dynamic bottom topography of such areas often result in strong currents that drive upwelling and increase ocean productivity (Croll et al. 2005; Tynan et al. 2005). In addition, the sand and gravel substrate around Cormorant Island and in other areas where Minke Whales are often found in the western and eastern North Atlantic (Naud et al. 2003; MacLeod et al. 2004; Robinson et al. 2009; de Boer 2010) can provide suitable burrowing or rearing habitat for Minke Whale prey, such as Pacific Sand Lance (Bizzarro et al. 2016) and Pacific Herring (Hay and McCarter 2006), respectively. Further studies on Minke Whales off Cormorant Island could focus on relations between their occurrence and temporal fluc-

\begin{tabular}{lll}
\hline \hline Date & Individual whale & \multicolumn{1}{c}{ Prey species } \\
\hline 18 Jul. 2012 & M004 & Pacific Sand Lance \\
20 Jul. 2012 & M022 & Pacific Herring \\
25 Jul. 2012 & M001 & Pacific Herring \\
26 Aug. 2012 & M006 or M004 & Pacific Herring \\
17 Jun. 2013 & M001 & Pacific Herring \\
17 Jun. 2013 & M001 & Pacific Herring \\
17 Jun. 2013 & M001 & Pacific Herring \\
17 Jun. 2013 & M001 & Pacific Herring \\
11 Sep. 2013 & M001 & Pacific Herring \\
11 Jun. 2014 & M001 & Pacific Sand Lance \\
11 Jun. 2014 & M001 & Pacific Sand Lance \\
14 Jun. 2014 & M006 & Pacific Herring \\
1 Jul. 2014 & M022 & Pacific Herring \\
1 Jul. 2014 & M022 & Pacific Herring \\
31 Jul. 2014 & M006 & Pacific Herring \\
7 Aug. 2014 & M001 & Pacific Herring \\
\hline \hline
\end{tabular}

tuations in the abundance and distribution of their prey and other environmental variables.

\section{Author Contributions}

Writing - Original Draft: J.T.; Writing - Review \& Editing: J.T., C.M., and R.P.; Conceptualization: J.T.; Investigation: J.T., C.M., and R.P.; Methodology: J.T. and C.M.; Formal Analysis: J.T., C.M., and R.P.; Funding Acquisition: J.T.

\section{Acknowledgements}

This research was funded in part by Mountain Equipment Co-op. We thank Debra Hughes, Jo Mrozewski, Leticiaá Legat, Bart Willis, Angelica Rose, Ivan $\mathrm{Ng}$, Samuel $\mathrm{Ng}$, Joe $\mathrm{Ng}$, and Nicole Borowczak for helping with the collection of field data, Bill Herbert and Wendy Thompson for supplying some materials, Dave Towers for logistical support, John Ford for input toward study design, and George Speck for permission to conduct this study from 'Namgis First Nation land.

\section{Literature Cited}

Barlow, J. 2010. Cetacean abundance in the California current estimated from a 2008 ship-based line-transect survey. Technical memorandum NOAA-TM-NMFS-SWFSC456. United States Department of Commerce, National Oceanic and Atmospheric Administration, La Jolla, California, USA.

Barlow, J., and K. Forney. 2007. Abundance and population density of cetaceans in the California current ecosystem. Fishery Bulletin 105: 509-26.

Bizzarro, J.J., A.N. Peterson, J.M. Blaine, J.P. Balaban, H.G. Greene, and A.P. Summers. 2016. Burrowing behaviour, habitat, and functional morphology of the Pacific sand lance (Ammodytes personatus). Fishery Bulletin 114: 445-460. https://doi.org/10.7755/fb.114.4.7 
Croll, D.A., B. Marinovic, S. Benson, F.P. Chavez, N. Black, R. Ternullo, and B.R. Tershy. 2005. From wind to whales: trophic links in a coastal upwelling system. Marine Ecology Progress Series 289: 117-130. https:// doi.org/10.3354/meps 289117

de Boer, M.N. 2010. Spring distribution and density of minke whale Balaenoptera acutorostrata along an offshore bank in the central North Sea. Marine Ecology Progress Series 408: 265-274. https://doi.org/10.3354/meps 08598

Dorsey, E.M., S.J. Stern, A.R. Hoelzel, and J. Jacobsen. 1990. Minke whale (Balaenoptera acutorostrata) from the west coast of North America: individual recognition and small-scale site fidelity. Report of the International Whaling Commission (special issue) 12: 357-368.

Ford, J.K.B. 2014. Marine Mammals of British Columbia. Royal BC Museum, Victoria, British Columbia, Canada.

Ford, J.K.B., R.M. Abernethy, A.V. Phillips, J. Calambokidis, G.M. Ellis, and L.M. Nichol. 2010. Distribution and relative abundance of cetaceans in western Canadian waters from ship surveys, 2002-2008. Canadian technical report of fisheries and aquatic sciences 2913. Fisheries and Oceans Canada, Nanaimo, British Columbia, Canada.

Ford, J.K.B., J.F. Pilkington, A. Reira, M. Otsuki, B. Gisborne, R.M. Abernethy, E.H. Stredulinsky, J.R. Towers, and G.M. Ellis. 2017. Habitats of special importance to resident Killer Whales (Orcinus orca) off the west coast of Canada. Canadian Science Advisory Secretariat research document 2017/035. Fisheries and Oceans Canada, Ottawa, Ontario, Canada.

Ford, J.K.B., A.L. Rambeau, R.M. Abernethy, M.D. Boogaards, L.M. Nichol, and L.D. Spaven. 2009. An assessment of the potential for recovery of Humpback Whales off the Pacific coast of Canada. Canadian Science Advisory Secretariat research document 2009/015. Fisheries and Oceans Canada, Ottawa, Ontario, Canada.

Ford, J.K.B., E.H. Stredulinsky, J.R. Towers, and G.M. Ellis. 2013. Information in support of the identification of critical habitat for transient Killer Whales (Orcinus orca) off the west coast of Canada. Canadian Science Advisory Secretariat research document 2012/155. Fisheries and Oceans Canada, Ottawa, Ontario, Canada.

Hay, D.E., and P.B. McCarter. 2006. Herring spawning areas of British Columbia: a review, geographic analysis and classification. Fisheries and Oceans Canada, Pacific Biological Station, Nanaimo, British Columbia, Canada.

Hoelzel, A.R., E.M. Dorsey, and S.J. Stern. 1989. The foraging specializations of individual minke whales. Animal Behaviour 38: 786-794. https://doi.org/10.1016/s00 03-3472(89)80111-3

Macleod, K., R. Fairbairns, A. Gill, B. Fairbairns, J. Gordon, C. Blair-Myers, and E.C.M. Parsons. 2004. Seasonal distribution of minke whales Balaenoptera acutorostrata in relation to physiography and prey off the Isle of Mull, Scotland. Marine Ecology Progress Series 277: 263-274. https://doi.org/10.3354/meps277263

McMillan, C.J., J.R. Towers, and J. Hildering. 2018. The innovation and diffusion of "trap feeding," a novel humpback whale foraging strategy. Marine Mammal Science 35: 779-796. https://doi.org/10.1111/mms.12557
Morton, A. 2000. Occurrence, photo-identification and prey of Pacific white-sided dolphins (Lagenorhyncus obliquidens) in the Broughton Archipelago, Canada 19841998. Marine Mammal Science 16: 80-93. https://doi. org/10.1111/j.1748-7692.2000.tb00905.x

Naud, M., B. Long, J. Brêthes, and R. Sears. 2003. Influences of underwater bottom topography and geomorphology on minke whale (Balaenoptera acutorostrata) distribution in the Mingan Island (Canada). Journal of the Marine Biological Association of the United Kingdom 83: 889-896. http://doi.org/dskq9c

Nichol, L.M., R.M. Abernethy, B.M. Wright, S. Heaslip, L.D. Spaven, J.R. Towers, J.F. Pilkington, E.H. Stredulinsky, and J.K.B. Ford. 2018. Distribution, movements and habitat fidelity patterns of Fin Whales (Balaenoptera physalus) in Canadian Pacific Waters. Canadian Science Advisory Secretariat research document 2017/004. Fisheries and Oceans Canada, Ottawa, Ontario, Canada.

Nichol, L.M., A.M. Hall, G.M. Ellis, E. Stredulinsky, M. Boogaards, and J.K.B. Ford. 2013. Dietary overlap and niche partitioning of sympatric harbor porpoises and Dall's porpoises in the Salish Sea. Progress in Oceanography 115: 202-210. https://doi.org/10.1016/j. pocean.2013.05.016

Nikolich, K., and J.R. Towers. 2018. Vocalizations of common minke whales (Balaenoptera acutorostrata) in an eastern North Pacific feeding ground. Bioacoustics. https://doi.org/10.1080/09524622.2018.1555716

Robinson, K.P., M.J. Tetley, and E.G. Mitchelson-Jacob. 2009. The distribution and habitat preference of coastally occurring minke whales (Balaenoptera acutorostrata) in the outer southern Moray Firth, northeast Scotland. Journal of Coastal Conservation 13: 39-48. https://doi.org/10.1007/s11852-009-0050-2

Towers, J.R. 2011. Minke Whales of the Straits off Northeastern Vancouver Island (Second Edition). Marine Education and Research Society, Alert Bay, British Columbia, Canada.

Towers, J.R., G.M. Ellis, and J.K.B. Ford. 2015. Photoidentification catalogue and status of the northern resident Killer Whale population in 2014. Canadian technical report of fisheries and aquatic sciences 3139 . Fisheries and Oceans Canada, Ottawa, Ontario, Canada.

Towers, J.R., M. Malleson, C.J. McMillan, J. Cogan, S. Berta, and C. Birdsall. 2018. Occurrence of fin whales (Balaenoptera physalus) between Vancouver Island and continental North America. Northwestern Naturalist 99: 49-57. https://doi.org/10.1898/nwn17-16.1

Towers, J.R., C.J. McMillan, M. Malleson, J. Hildering, J.K.B. Ford, and G.M. Ellis. 2013. Seasonal movements and ecological markers as evidence for migration of common minke whales photo-identified in the eastern North Pacific. Journal of Cetacean Research and Management 13: 221-229.

Towers, J.R., G.J. Sutton, T.J.H. Shaw, M. Malleson, D. Matkin, B. Gisborne, J. Forde, D. Ellifrit, G.M. Ellis, J.K.B. Ford, and T. Doniol-Valcroze. 2019. Photoidentification catalogue, population status, and distribution of Bigg's killer whales known from coastal waters of British Columbia, Canada. Canadian technical 
report of fisheries and aquatic sciences 3311. Fisheries and Oceans Canada, Ottawa, Ontario, Canada.

Tynan, C.T., D.G. Ainley, J.A. Barth, T.J. Cowles, S.D. Pierce, and L.B. Spear. 2005. Cetacean distributions relative to ocean processes in the northern California Current system. Deep-Sea Research II 52: 145-167. https://doi.org/10.1016/j.dsr2.2004.09.024

Walker, W.A., M.B. Hanson, R.W. Baird, and T.J. Guenther. 1998. Food habits of the harbor porpoise, Phocoena phocoena, and the Dall's porpoise, Phocoenoides dalli, in the inland waters of British Columbia and
Washington. Pages 63-75 in Marine Mammal Protection Act and Endangered Species Act Implementation Program 1997. AFSC processed report 98-10. National Marine Fisheries Service, Seattle, Washington, USA.

Williams, R., and L. Thomas. 2007. Distribution and abundance of marine mammals in the coastal waters of British Columbia, Canada. Journal of Cetacean Research and Management 9: 15-28.

Received 11 June 2018

Accepted 17 January 2019 